Original Russian Text (C) 2020 O.V. Martynenko, V.N. Karminov, P.V. Ontikov published in Forest Science Issues Vol. 3, No. 2, pp. 1-12

DOI $10.31509 / 2658-607 x-2021410$

\title{
INFLUENCE OF ANTHROPOGENIC FACTORS ON THE SOIL CONDITION OF THE N.V. TSITSIN MAIN BOTANICAL GARDEN OF RAS
}

\author{
O.V. Martynenko ${ }^{1 *}$, V.N. Karminovi.2.3, P.V. Ontikov ${ }^{4}$ \\ ${ }^{1}$ All-Russian Institute of Continuous Education in Forestry (ARICEF) \\ Insitutskaya st. 20, Pushkino, Moscow region, 141200, Russian Federation \\ ${ }^{2}$ Center for Forest Ecology and Productivity of the Russian Academy of Sciences \\ Profsoyuznaya st. 84/32 bldg. 14, Moscow, 117997, Russian Federation \\ ${ }^{3}$ Mytischi Branch of Bauman Moscow State Technical University \\ 1st Institutskaya street, 1, Mytischi, Moscow region, 141005, Russian Federation \\ ${ }^{4}$ Federal forestry agency FSBI «ROSLESINFORG» «CENTRLESPROEKT» \\ Zavodskaya st. 10, Ivanteevka, Moscow region, 141200, Russian Federation
}

*E-mail: martinen75@yandex.ru

Received 03.03.2020

Accepted 03.06.2020

The territory of the N.V. Tsitsin Main Botanical Garden of the Russian Academy of Sciences is subjected to significant anthropogenic stress, which has a negative effect on the state of valuable collections of tree and shrub species. Soil compaction is one of the most dangerous consequences of anthropogenic impact, expressed in increased recreational impact. In this context, the botanical garden was very concerned about the deterioration of the collection of elaeagnus species. Therefore, the soils on which these plants grow were chosen as the object of research. On this territory, three sampling plots with different degrees of anthropogenic impact were laid. Sampling plot No. 1 had the maximum anthropogenic impact. The area of medium anthropogenic impact was represented by the sampling plot No. 2. The sampling plot No. 3 where the anthropogenic impact was minimal was a reference plot. All the studied soils were classified as soddy-slightly podzolic medium loamy soils (Umbric Albeluvisols Abruptic). Fundamental differences in the morphological properties of the studied soils were that the soils located in the area of maximum anthropogenic impact, starting from a depth of $40 \mathrm{~cm}$, showed gley spots, which were not found in other soils. Increased bulk density of soil in undisturbed state corresponded to increased anthropogenic impact. This led to a decrease in total pore space of soil. Soil compaction contributed to a noticeable decrease in gravimetric soil water content in upper horizons. At the same time, worsening of subsurface runoff contributed to gleyforming processes in the illuvial part of the profile. Cluster analysis revealed good grouping of the dependence of the studied indicators on the severity of anthropogenic impact. The studied indicators were separated depending on their type and position in the profile. The conducted study made it possible to assess the essential physical and hydrophysical properties of soils on the part of the territory of the Main Botanical garden of RAS that is occupied by the valuable collection of elaeagnus. Based on the results of the study, a set of measures is proposed that can significantly reduce the identified negative effects and improve the state of both the studied soils and stands growing on them in general.

Key words: bulk density of soil, anthropogenic compaction, soils of botanical gardens, GBS $R A S$ 
N.V. Tsitsin Main Botanical Garden of the Russian Academy of Sciences (GBS RAS) can be justly put on the list of the most interesting and well-known botanical gardens in the world. Opened in 1945, it compactly accommodates unique collections of tree and shrub species from all over the world (Demidov et al., 2016). By the decree of the Presidium of the USSR Academy of Sciences on December 2, 1991 the Main Botanical Garden was named after the member of the Academy of Sciences Nikolai Vasilievich Tsitsin.

GBS RAS is the largest botanical garden in Europe. For the convenience of visitors and employees, the botanical garden has an extensive network of asphalt and dirt paths. Such a well-developed trail and path network allows for both easy hikes and active sports including running and cycling. High profile of the botanical garden among Muscovites and metropolitan visitors results into strong anthropogenic impact on its stands and soils (Grevtsova, Rysin, 2020).

The main issue with the soils of recreational areas is their compaction caused by heavy traffic of vehicles, people and animals. Soil compaction decreases the total pore space by $30-50 \%$, primarily due to micropores, which play a central role in the movement of water and air as well as the spread and growth of plant roots. This directly affects the basic hydrophysical properties of the soil: on the one hand, water permeability decreases, and therefore conditions that favour water stagnation are created, which is best seen in illuvial horizons; on the other hand, the compaction of the upper humus horizon reduces the ability of soil to absorb and retain moisture. The negative impact of anthropogenic compaction on the crucial soil properties was reported by many researchers (Smagin et al., 2006; Lysikov, 2006, 2008, 2011; Yakovlev, Evdokimova, 2011; Melankholin, Lysikov, 2014; Stoma, 2016; Zakharov, Kulik, 2017; Muracheva, 2018). It is usually not so much the over-compaction of soil on the paths as the preservation of unique park cenoses, where a variety of vegetation is represented, that causes concern (Mosina, 2003).

It should be noted that some authors consider the soils of botanical gardens some kind of unique formation that differs from both natural and urban green areas and was formed due to constant introduction of soil fauna and microorganisms on plant roots and in soil as well as long-term (for decades and even centuries) anthropogenic (urbanogenic) impact (Rappoport et al., 2013). Thus, urban botanical gardens are unique artificially created ecosystems, where the negative impact of the urban environment is partially offset and there is a high level of biodiversity. This study was performed within that narrative, and the objective of the study was to identify and evaluate the likely impact of the complex of soil factors on the condition of stands (collection of elaeagnus species) of the GBS RAS.

\section{MATERIALS AND METHODS}

This research was carried out as part of a comprehensive soil and hydrotechnical survey of the territory of the GBS RAS conducted by the staff and students of Mytishchi branch of N.E. Bauman Moscow State Technical University. Special emphasis was made on looking into the influence of anthropogenic factors on soil properties, which, in turn, largely determine the conditions for the growth and development of tree and shrub species growing in the botanical garden (Rysin, Grevtsova, 2018). According to our tentative hypothesis, it was the anthropogenic compaction that could cause the death of the collection of Elaeagnus. Most likely, the paths made worsened the outflow of groundwater and led to soil waterlogging in the spring.

The study program included laying three sampling plots each $20 \times 20 \mathrm{~m}$ of size. Two sampling plots were located directly on the territory of the collection of elaeagnus. Sampling plot No. 1 was laid at a distance of 
about 10 meters from a busy central pedestrian walkway. This sampling plot represented the part of the territory occupied by the collection of elaeagnus with the highest anthropogenic impact. Stage 4 of recreational degradation was diagnosed for this area. Sampling plot No. 2 was located at a distance of about 20 meters from the central alley, next to a small path, where the anthropogenic impact was moderate. In this zone, recreational degradation was at stage 3. As a reference plot, sampling plot No. 3 was laid down in a relatively inaccessible place, where visitors to the garden do not get very often. The distance from the central pedestrian walkway was about 50 meters. Stage 2 of recreational degradation was stated in this area.

During the field research phase, at each sampling plot 5-6 test pits were made. For each sampling plot, one most typical test pit was deepened to form a section. Thus, section B3 (N55.842984, E37.598317) was located in the area of maximum anthropogenic impact. The area with moderate anthropogenic impact was represented by section B2 (N55.84282, E37.59879), whereas the control section B1 (N55 N55.842588, E37.598169) was laid in the area with low anthropogenic impact. All locations are given in the WGS84 system.

For the soil sections and pits, a complete morphological description was performed according to the methods used in soil science. Samples were taken from all sections on genetic horizons to determine the general physical and hydrophysical properties of soils at the soil laboratory of a department of Mytishchi branch of N.E. Bauman Moscow State Technical University. In particular, bulk density in the undisturbed natural state (according to N.A. Kachinski), field gravimetric soil water content by weight method and the total pore space of soil were determined. Assessment of soil parameters provided results within $5 \%$ in terms of accuracy of the experiment at a significance level of 0.05 (Vadyunina, Korchagina, 1986).
The selection of soil sampling points, georeferencing of the sections made, and land navigation were carried out using modern geoinformation systems. For the study, a combination of the NextGIS mobile application for Android and the Quantum GIS desktop application was chosen, the latter was used for combining and systematization of all the obtained geodata. The QGIS system has been an almost absolute leader in recent years in the free software class (Shokin, Potapov, 2015).

The obtained experimental data were processed using multidimensional statistical methods, more specifically, cluster analysis. For the studied objects, dendrograms were constructed, with the values of similarity (or difference) represented on the $\mathrm{Y}$ axis, and the numbers of objects with equal intervals represented on the $\mathrm{X}$ axis. The normalized Euclidean distance was chosen as a measure of difference: the geometric distance between objects in a multidimensional feature space. For clustering, Ward's method was used. Analysis of variance method was used in this study to estimate distances between clusters. The distance between clusters is seen as the increase in the sum of squared distances from objects to the centre of the cluster, obtained as a result of their union.

\section{RESULTS AND DISCUSSION}

Field studies showed that all the surveyed soils are Umbric Albeluvisols Abruptic (WRB, 2015). The grain size did not change significantly along the profile. Bigger grain size was found only in the lowest part of the profile in the transition horizons to the parent rock.

The main difference in the morphological properties of the studied soils was that in the soils located in the area of maximum anthropogenic impact, starting from a depth of $40 \mathrm{~cm}$ there were gley spots which were not found in soils with low and medium anthropogenic impact. The main 
characteristics of soils are presented in Table 1 .

The lowest bulk density of soil in the undisturbed state is observed in the area of the minimum anthropogenic impact (Fig. 1). This trend is typical for the depth of the studied soil profile. Natural vegetation with a predominance of birch and mixed herbs in the ground cover at $0.97 \mathrm{~g} / \mathrm{cm}^{3}$ provided a fairly favourable density of the upper horizon $\mathrm{A}_{1}$. Density expectedly increases with the depth, reaching a maximum of $1.48 \mathrm{~g} / \mathrm{cm}^{3}$ in the $B$ horizon. For the other two sections located in the area of strong anthropogenic impact, the density of the upper horizon $A_{1}$ is substantially higher $\left(1.29 \mathrm{~g} / \mathrm{cm}^{3}\right.$ and $\left.1.25 \mathrm{~g} / \mathrm{cm}^{3}\right)$ near the walkway and the path, respectively. Although there is a walkway surfaced with good asphalt, some visitors still go off the paths, which leads to soil compaction, and the compacting effect reaches a considerable depth and is seen up to and including the illuvial horizon B.

Of course, these density values have a negative impact on both the state of the soil itself and vegetation, but for comparison, it should be noted that in similar studies, soil density figures in the middle of the path were up to $1.8 \mathrm{~g} / \mathrm{cm}^{3}$ (Lysikov, 2008, 2017). Thus, the regular network of well-maintained paths of the GBS still takes on the main load.

Table 1. Bulk density, total and field gravimetric soil water content

\begin{tabular}{|c|c|c|c|c|c|c|c|}
\hline $\begin{array}{c}\text { Sequence } \\
\text { No. }\end{array}$ & $\begin{array}{c}\text { Severity of } \\
\text { anthropogenic } \\
\text { impact }\end{array}$ & Horizon & $\begin{array}{c}\text { Horizon } \\
\text { boundaries } \\
\text { (thickness), } \\
\mathrm{cm}\end{array}$ & $\begin{array}{l}\text { Depth of } \\
\text { sampling, } \\
\mathrm{cm}\end{array}$ & $\begin{array}{c}\text { Bulk } \\
\text { density of } \\
\text { soil, } \mathrm{g} / \mathrm{cm}^{3}\end{array}$ & $\begin{array}{l}\text { Total pore } \\
\text { space of } \\
\text { soil, } \%\end{array}$ & $\begin{array}{c}\text { Field } \\
\text { gravimetric } \\
\text { soil water } \\
\text { content, \% }\end{array}$ \\
\hline \multirow{5}{*}{1} & \multirow{5}{*}{ maximum } & $\mathrm{A}_{1}$ & $2 \ldots 14(12)$ & $5 \ldots 15$ & $1.29 \pm 0.05$ & $52.16 \pm 2.59$ & $36.34 \pm 1.88$ \\
\hline & & $\mathrm{A}_{1} \quad \mathrm{~A}_{2}$ & $14 \ldots .29(15)$ & $18 \ldots 28$ & $1.60 \pm 0.04$ & $40.94 \pm 1.76$ & $25.40 \pm 1.17$ \\
\hline & & $\mathrm{A}_{2}$ & $29 \ldots 43(14)$ & $31 \ldots 41$ & $1.76 \pm 0.05$ & $35.28 \pm 0.99$ & $20.48 \pm 0.90$ \\
\hline & & $\mathrm{A}_{2} \mathrm{~B}$ & $43 \ldots 62$ (19) & $47 \ldots .57$ & $1.77 \pm 0.05$ & $35.40 \pm 1.16$ & $15.94 \pm 0.45$ \\
\hline & & $\mathrm{Bg}$ & $62 \ldots$ & $63 \ldots 73$ & $2.02 \pm 0.05$ & $26.16 \pm 1.03$ & $16.66 \pm 0.77$ \\
\hline \multirow{5}{*}{2} & \multirow{5}{*}{ medium } & $\mathrm{A}_{1}$ & $1 \ldots 18(17)$ & $4 \ldots 14$ & $1.15 \pm 0.04$ & $57.44 \pm 1.57$ & $34.24 \pm 0.68$ \\
\hline & & $\mathrm{A}_{1} \quad \mathrm{~A}_{2}$ & $18 \ldots 35$ (17) & $22 \ldots 32$ & $1.33 \pm 0.06$ & $51.10 \pm 2.13$ & $28.20 \pm 1.38$ \\
\hline & & $\mathrm{A}_{2}$ & $35 \ldots 43(8)$ & $35 \ldots 43$ & $1.61 \pm 0.06$ & $40.88 \pm 1.22$ & $20.66 \pm 1.00$ \\
\hline & & $\mathrm{A}_{2} \mathrm{~B}$ & $43 \ldots 61(18)$ & $48 \ldots .58$ & $1.66 \pm 0.06$ & $38.86 \pm 1.38$ & $16.88 \pm 0.78$ \\
\hline & & B & $61 \ldots$ & $62 \ldots 72$ & $1.74 \pm 0.05$ & $36.02 \pm 1.50$ & $18.10 \pm 0.90$ \\
\hline \multirow{5}{*}{3} & \multirow{5}{*}{ low } & $\mathrm{A}_{1}$ & $1 \ldots 24(23)$ & $5 \ldots 15$ & $0.97 \pm 0.03$ & $64.24 \pm 1.68$ & $42.62 \pm 1.32$ \\
\hline & & $\mathrm{A}_{1} \quad \mathrm{~A}_{2}$ & $24 \ldots 34(10)$ & $24 \ldots 34$ & $1.10 \pm 0.05$ & $60.07 \pm 1.61$ & $33.12 \pm 1.38$ \\
\hline & & $\mathrm{A}_{2}$ & $34 \ldots 44(10)$ & $34 \ldots 44$ & $1.38 \pm 0.06$ & $48.98 \pm 1.50$ & $22.16 \pm 0.99$ \\
\hline & & $\mathrm{A}_{2} \mathrm{~B}$ & $44 \ldots . .54(10)$ & $44 \ldots . .54$ & $1.18 \pm 0.05$ & $57.23 \pm 1.11$ & $22.72 \pm 0.89$ \\
\hline & & B & $54 \ldots$ & $55 \ldots 65$ & $1.48 \pm 0.06$ & $46.04 \pm 1.88$ & $11.78 \pm 0.55$ \\
\hline
\end{tabular}




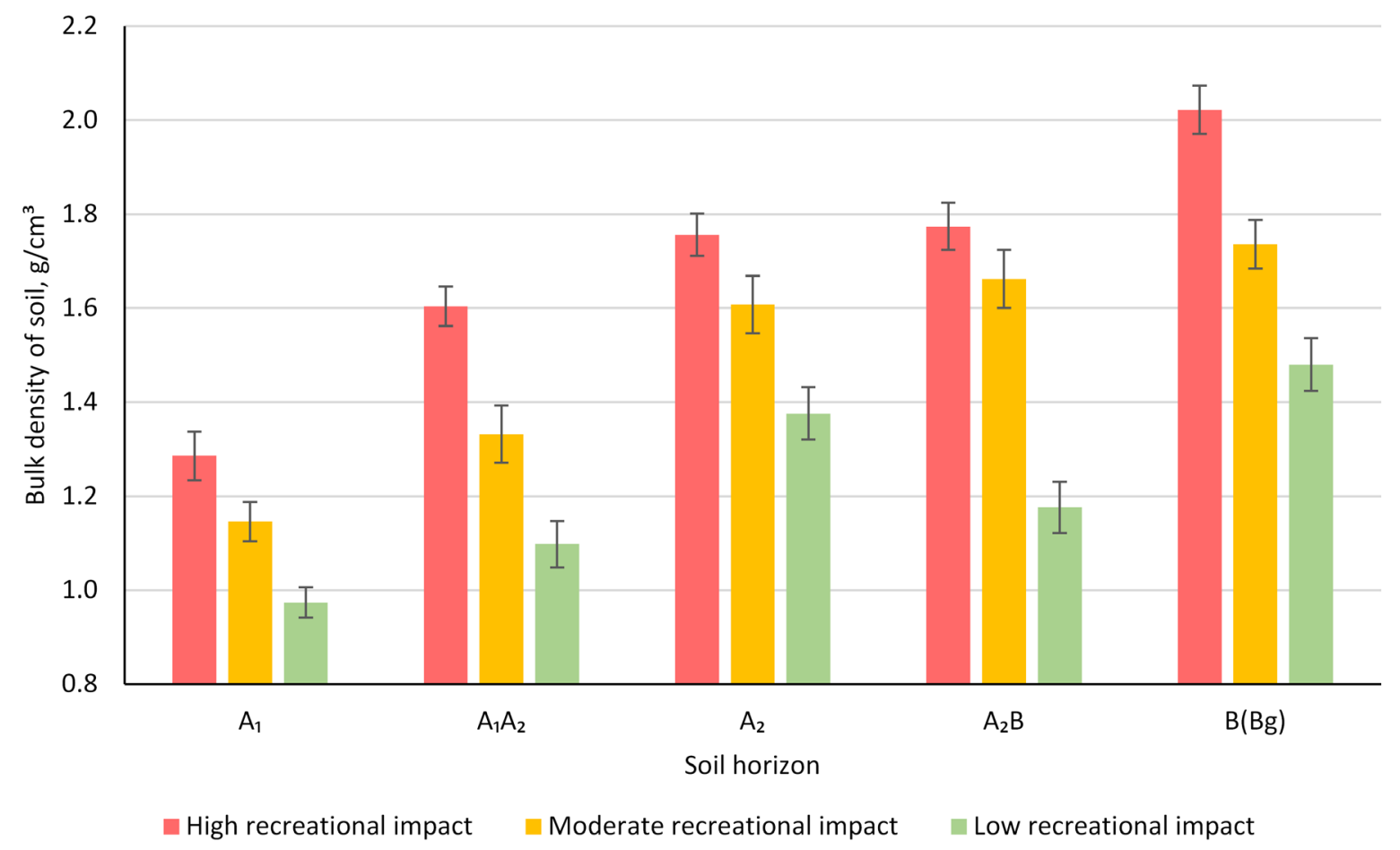

Figure 1. Changes in bulk density of soil depending on anthropogenic impact

The above-mentioned increase in soil density in areas with high and medium anthropogenic impact leads to a decrease in its total pore space (Fig. 2), primarily due to the air pore space, but the capillary pore space also decreases.

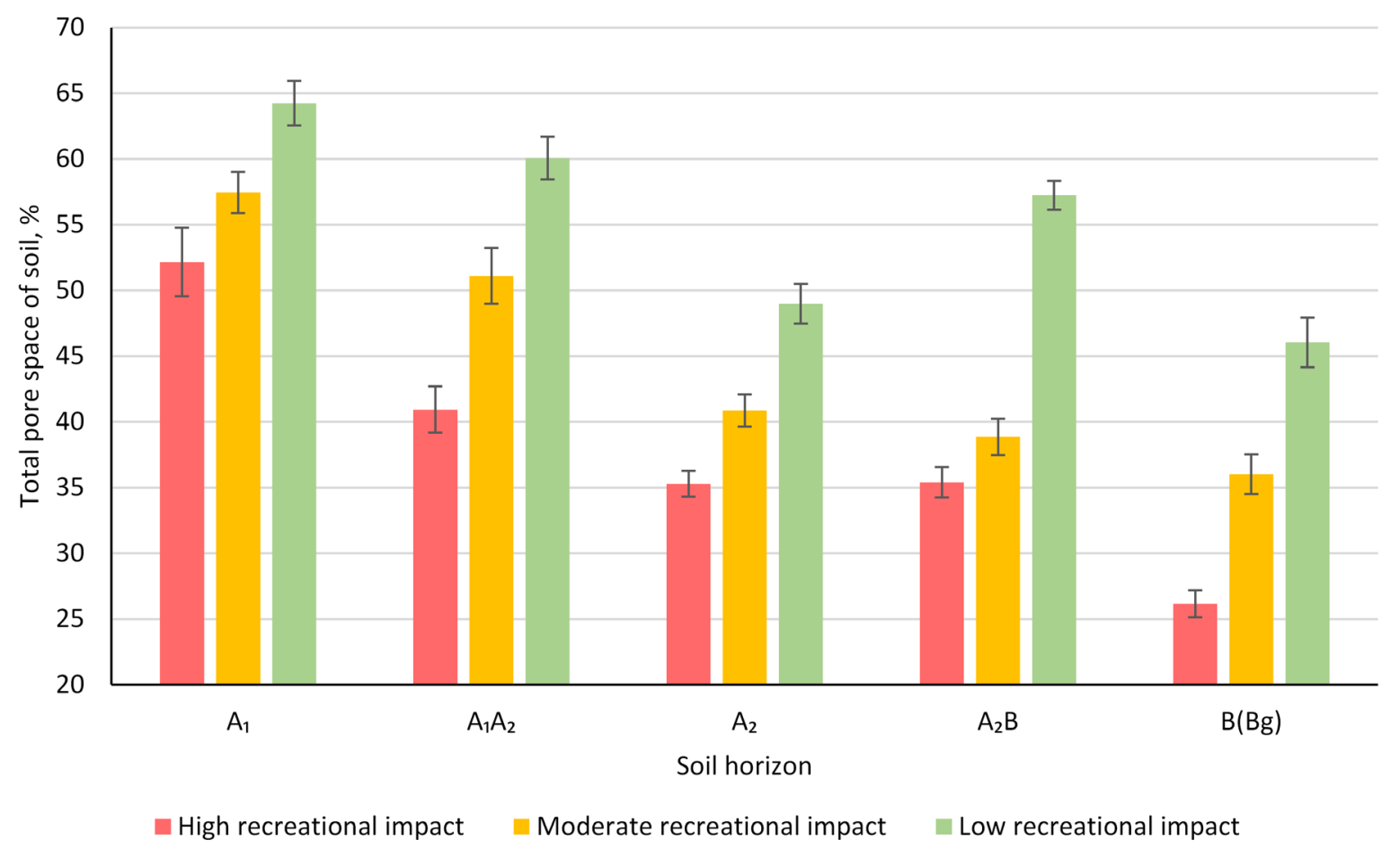

Figure 2. Changes in total pore space of soil depending on the anthropogenic impact 
Due to all this, field gravimetric soil water content of the compacted horizons decreases significantly (Fig. 3). This is especially visible in the section located near the central walkway.

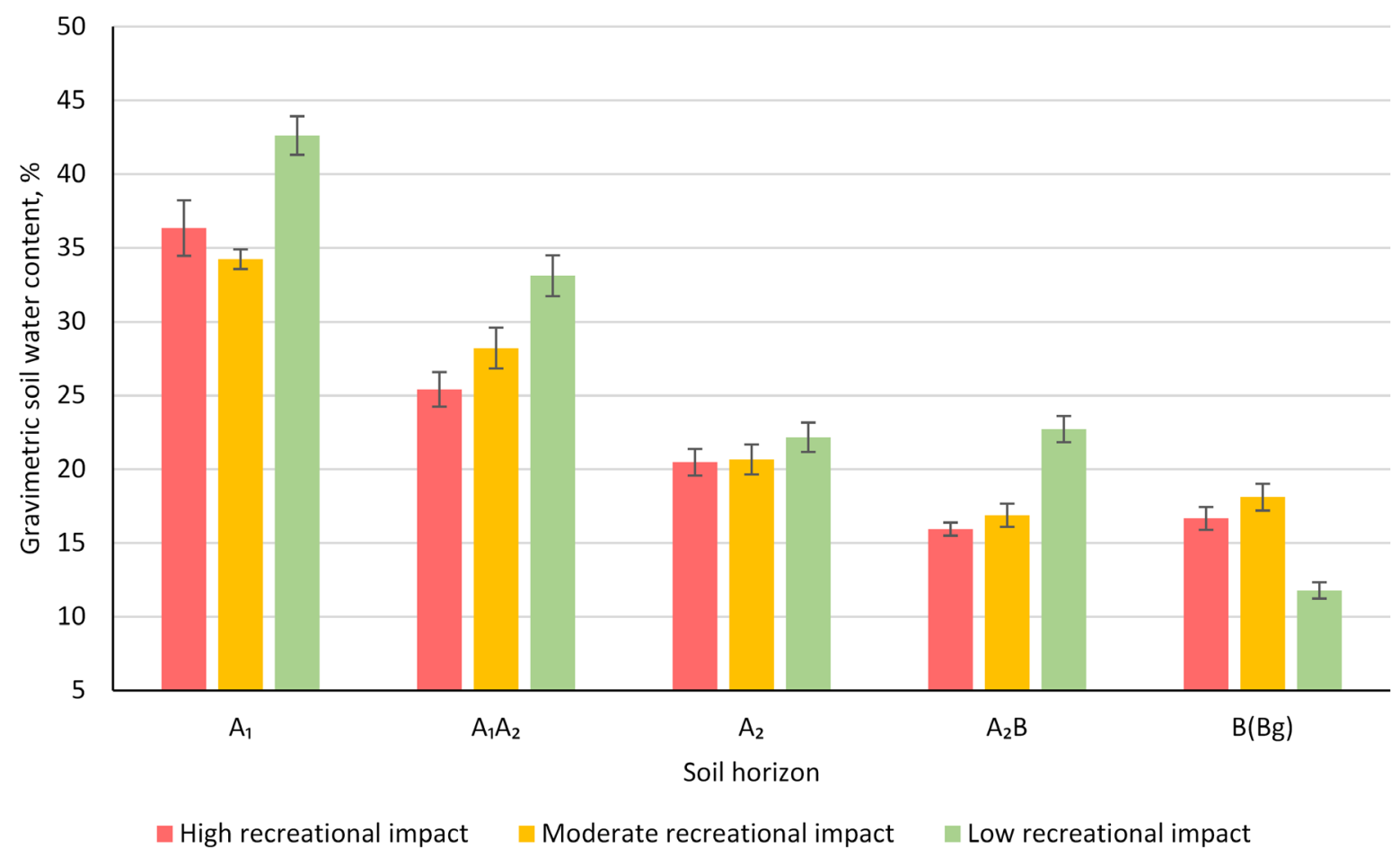

Figure 3. Changes in gravimetric soil water content depending on anthropogenic impact

When looking at the data obtained, one cannot but agree with S.G. Zakharov (2107), who pointed out that in forested landscapes, paths are not an innocent element anymore, but a kind of suffocating network that breaks down the original woodland into increasingly isolated areas with pulsating and expanding patches of soil and vegetation cover degradation.

Increased loss of water from the upper horizon might also be facilitated by the forest live cover which suffers from trampling and therefore has lower species diversity and smaller projective cover than in the area not easily accessible for visitors.

Low water permeability negatively affects the growth and development of plants, increasing the risk of their death from drowning. Most likely, that very reason caused the death of the collection of elaeagnus on the territory of the N.V. Tsitsin GBS RAS. It could have been avoided by timely and appropriate reclamation measures.

According to the cluster analysis, based on all the obtained soil indicators, areas with maximum and medium anthropogenic impact formed specific groups, whereas the territory with a low level of such impact could be separated quite early (Fig. 4).

Thus, the changes in soil indicators allow us to state that even medium anthropogenic impact significantly affects the state of soil. 

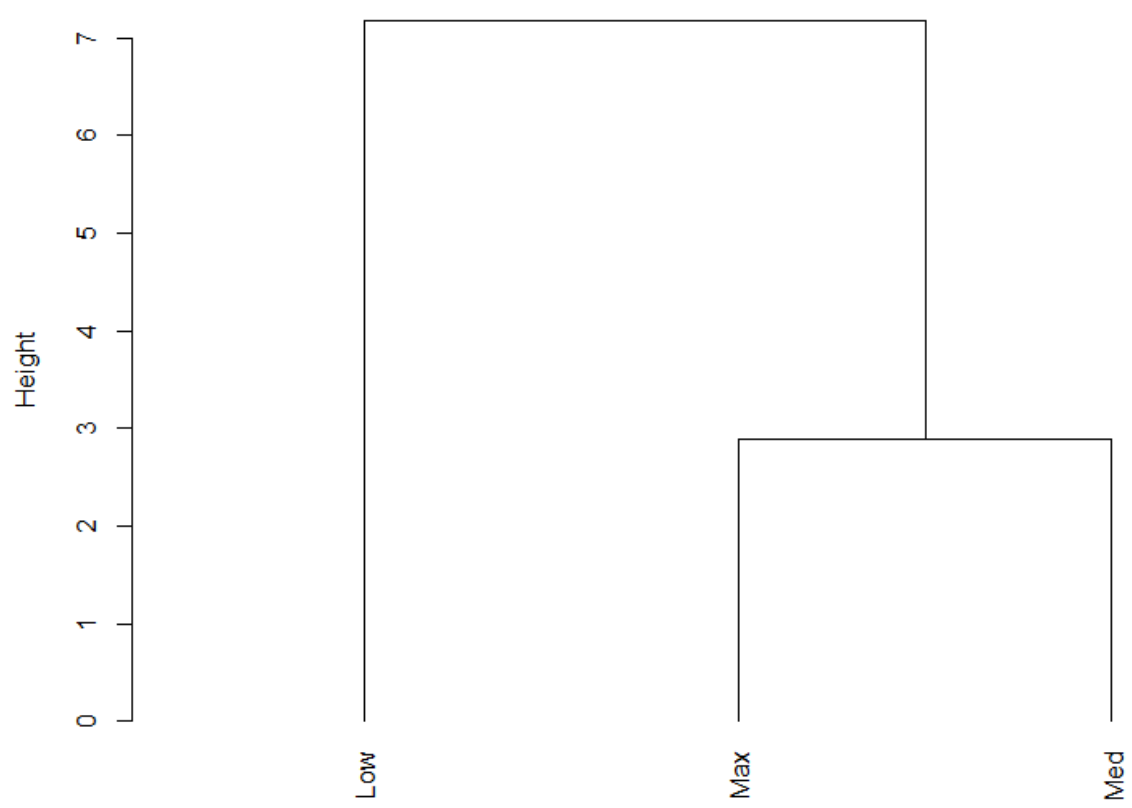

Figure 4. Dendrogram of the studied objects ("Low" - low impact zone, "Med" - medium impact zone, "Max" - maximum impact zone)

Fig. 5 shows the distribution of soil parameters (properties) in a multidimensional space. The figure shows three areas of indicator clustering. The first one is the largest and includes the values of total pore space and gravimetric soil water content of the upper genetic horizons. The second area of grouping located in the centre of the dendrogram included only the values of the bulk density of soil in the undisturbed state. Moreover, a noticeable division into conditionally "upper", "middle" and "lower" horizons is already observed within this group.

Cluster Dendrogram

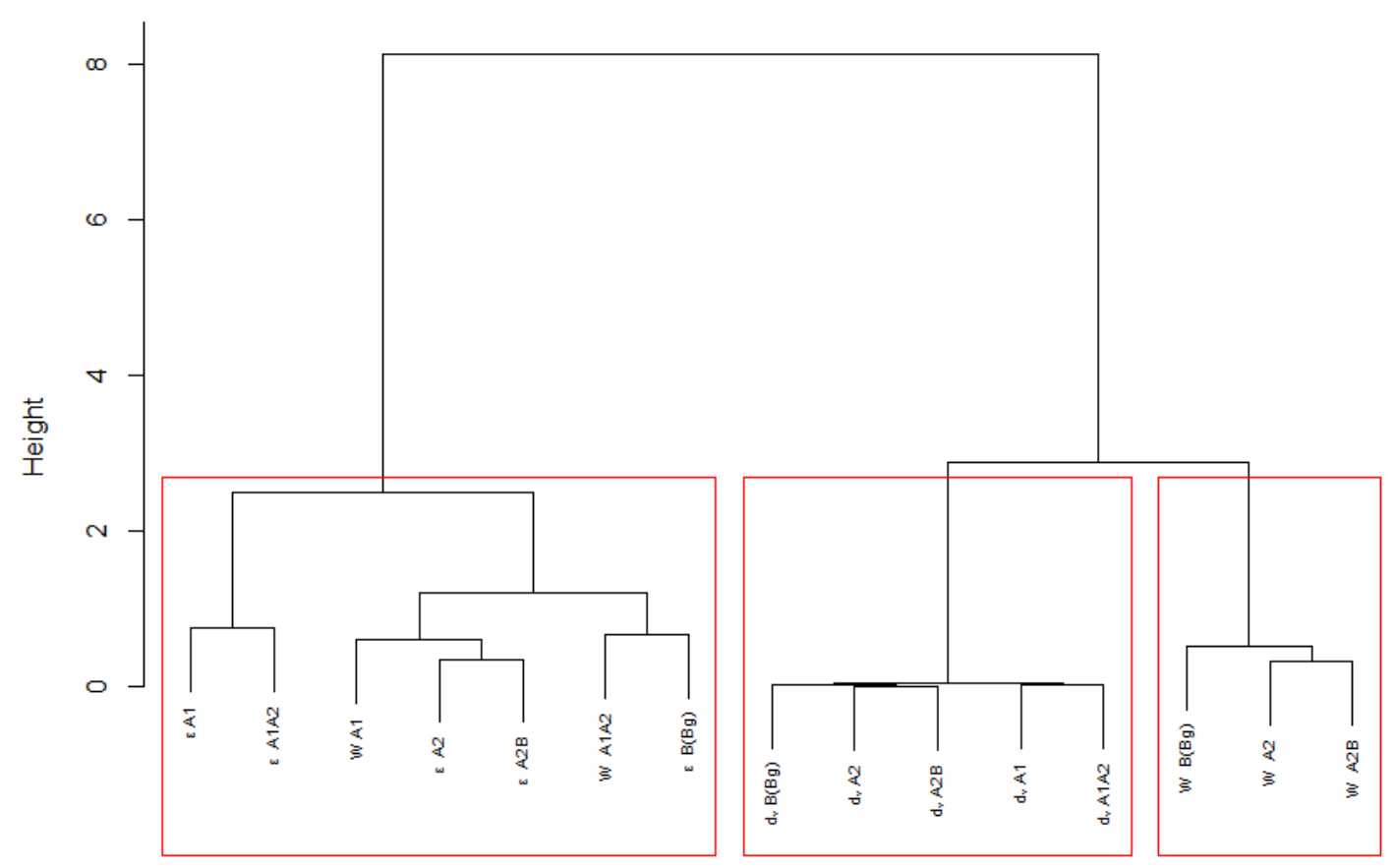

Figure 5. Dendrogram of the properties of genetic horizons of the studied objects $(\varepsilon-$ total pore space, $d_{v}-$ bulk density in undisturbed state, $\mathrm{W}$ - field gravimetric soil water content) 
The last (third) and smallest group included the gravimetric soil water content of the eluvial and illuvial horizons, which may indicate that groundwater and perched water start to play a significant role here.

It should be noted that this method made it possible to present the relationship between the studied indicators and the value of anthropogenic impact in a well-structured fashion, and these results are quite explainable from the perspective of the scientific theory.

Based on the results of the study, some practical guidelines can be formulated to mitigate the observed negative consequences. Reconstruction of the roadway and addition of elements of selective closed material drainage to it can be recommended as first and most transformative measures to control moisture stagnation (caused by over-compaction and disturbance of the subsurface runoff). In areas of the most critical compaction, material or non-material air drainage should be used. Moreover, special emphasis should be made on controlling the flow of visitors using hedges and on the intensification of informational work with the botanical garden visitors.

\section{CONCLUSION}

The performed study made it possible to evaluate the most important physical and

\section{REFERENCES}

Demidov A.S., Rysin S.L., Kobyakov A.V., Vozmozhnosti ispol'zovaniya GIStehnologii $\mathrm{v}$ rabote botanicheskikh sadov (Possibilities of using GIS technologies in the work of Botanical gardens), Lesokhozyaistvennaya informatsiya, 2014, No. 4, pp. 68-72.

Demidov A.S., Shustov M.V., Potapova S.A., Sokhranenie raznoobraziya rastitel'nogo mira Rossii v Glavnom botanicheskom sadu im. N.V. Tsitsina (Preserving the diversity of the Russian flora in the main Botanical garden named after N.V. Tsitsin), Sokhranenie raznoobraziya rastitel'nogo mira $v$ botanicheskikh sadakh: traditsii, sovremennost', perspektivy. Materialy Mezhdunarodnoi konferentsii, hydrophysical properties of soils of the part of the Main Botanical Garden RAS, occupied by the collection of elaeagnus and affected by anthropogenic impact of different intensity. A noticeable increase in the bulk density of soil in undisturbed state in the area of medium and maximum anthropogenic impact was found. Consistent with increased density, a decrease in the total pore space and gravimetric soil water content of the studied soils was observed. Cluster analysis showed that, in terms of the totality of the studied indicators, areas with maximum and medium anthropogenic impact are more similar to each other than to the area with low anthropogenic impact. Even the anthropogenic impact that is deemed medium significantly affects all of the most important general physical and hydrophysical properties of soils.

The results of the study will form the basis for the development of detailed practical guidelines aimed at mitigation of the negative effects of human impact on soils of the GBS RAS and these findings will be included into the soil section of the integrated geographic information system of the GBS RAS and can then be used for assessment and monitoring of soils and plants in arboreta and enhance the recreational potential of the territory of the Botanical garden.

\section{posvyashchennoi 70-letiyu Tsentral'nogo} sibirskogo botanicheskogo sada (Preserving the Diversity of the Plant World in Botanical Gardens: Traditions, Modernity, Prospects, Proceedings of the International Conference Dedicated to the $70^{\text {th }}$ Anniversary of Central Siberian Botanical Garden), 2016, pp. 96-98.

Grevtsova V.V., Rysin S.L., O neobkhodimosti sozdaniya tsentra po izucheniyu dubrav na urbanizirovannykh territoriyakh $\mathrm{v}$ Glavnom botanicheskom sadu RAN (About the need to create a center for the study of oak forests in urban areas in the Main Botanical Garden of the Russian Academy of Sciences), Nauchnye trudy Cheboksarskogo filiala Glavnogo 
botanicheskogo sada im. N.V. Tsitsina $R A N, 2020$, No.15, pp. 120-122.

Lysikov A.B., Izmeneniya pochvennoekologicheskikh uslovii $\mathrm{v}$ lesnykh biogeotsenozakh pod vliyaniem rekreatsii (Changes in soil and environmental conditions in forest biogeocenoses under the influence of recreation), Aktual'nye problemy lesnogo kompleksa, 2006, No. 13, pp. 79-82.

Lysikov A.B., Izmenenie plotnosti lesnykh pochv pri rekreatsii (Change in forest soil density during recreation), Lesovedenie, 2008, No. 4, pp. 44-49.

Lysikov A.B., Vliyanie rekreatsii na sostoyanie pochv v gorodskikh listvennykh lesakh (The effect of recreation on the state of soils in urban deciduous forests), Lesovedenie, 2011, No. 4, pp. 11-20.

Melankholin P.N., Lysikov A.B., Vliyanie dorozhno-tropinochnoi seti na travyanuyu rastitel'nost' i pochvy dubovykh lesov Moskvy i blizhnego Podmoskov'ya (The influence of the road-path network on the grassy vegetation and soils of the oak forests of Moscow and the near Moscow region), Lesovedenie, 2014, No. 2, pp. 3845.

Mosina L.V., Antropogennoe izmenenie lesnykh ekosistem v usloviyakh megapolisa Moskva, avtoreferat dis. ... doktora biologicheskih nauk (Anthropogenic change of forest ecosystems under the conditions of the Moscow megacity), Moskow, Moscow Timiryazev Agricultural Academy, 2003, 38 p.

Muracheva L.S., Uplotnenie pochvy kak faktor ekologicheskikh problem parkovykh ekosistem (Soil compaction as a factor in the environmental problems of park ecosystems). Ekologicheskie problemy prirodnykh $i$ urbanizirovannykh territorii. Materialy IX Mezhdunarodnoi nauchnoprakticheskoi konferentsii (Ecological Problems of Natural and Urbanised Territories. Proceedings of the $19^{\text {th }}$ International Scientific and Practical Conference), 2018, pp. 85-89.

Rappoport A.V., Lysak L.V., Marfenina O.E., Rakhleeva A.A., Stroganova M.N., Terekhova V.A., Makarova N.V.,
Aktual'nost' provedeniya pochvennoekologicheskikh issledovanii V botanicheskikh sadakh (na primere Moskvy i Sankt-Peterburga) (Relevance of soil and environmental research in Botanical gardens (on the example of Moscow and St. Petersburg)), Byulleten'Oobshchestva ispytatelei prirody (MOIP), 2013, Vol. 118, Issue 5, pp. 45-56.

Rysin S.L., Grevtsova V.V., Problemy sohraneniya zapovednoi dubravy na territorii GBS RAN (Problems of conservation of protected oak grove on the territory of the GBS RAS). Sbornik materialov $\quad X X \quad$ Mezhdunarodnogo nauchno-prakticheskogo foruma "Problemy ozeleneniya krupnykh gorodov" Sbornik materialov foruma $v$ ramkah Mezhdunarodnoj vystavki "Tsvety - 2018" (Proc. of the XX International scientific and practical forum "Problems of Greening of Large Cities"), 2018, pp. 123-126.

Rysin S.L., Plotnikova L.S., Trusov N.A., Yatsenko I.O., Novye podkhody $\mathrm{k}$ organizatsii monitoringa sostoyaniya rastenii $\mathrm{v}$ dendrologicheskikh kollektsiyakh (New approaches to monitoring the state of plants in dendrological collections), Byulleten' Glavnogo botanicheskogo sada, 2015, No. 2, pp. 15-22.

Rysin S.L., Trusov N.A., Yatsenko I.O., Osobennosti organizatsii monitoringa tsennyh drevesnyh rastenii na urbanizirovannykh territoriyakh (Features of monitoring valuable woody plants in urban areas), Vestnik Moskovskogo gosudarstvennogo universiteta lesa Lesnoi vestnik, 2015, Vol. 19, No. 5, pp. 140-144.

Shokin Yu.I., Potapov V.P., GIS segodnya: sostoyanie, perspektivy, resheniya (GIS today: state, prospects, solutions), Vychislitel'nye tekhnologii, 2015, No. 5, pp. 175-213.

Smagin A.V., Azovtseva N.A., Smagina M.V., Stepanov A.L., Myagkova A.D., Kurbatova A.S., Nekotorye kriterii i metody otsenki ekologicheskogo sostoyaniya pochv $\mathrm{v}$ svyazi s ozeleneniem gorodskikh territorii (Some criteria and methods for assessing the ecological state of soils in connection 
with the greening of urban areas), Pochvovedenie, 2006, No. 5, pp. 603-615.

Stoma G.V., Ekologicheskoe sostoyanie pochv i drevesnykh nasazhdenii selitebnykh landshaftov g. Moskvy (The ecological state of soils and tree plantings of residential landscapes in Moscow), Vestnik Moskovskogo universiteta, 17: Pochvovedenie, 2016, No. 1, pp. 41-48.

Vadyunina A.F., Korchagina Z.A., Metody issledovaniya fizicheskikh svoistv pochv (Methods for studying the physical properties of soils), Moscow: Agropromizdat, 1986, $416 \mathrm{p}$.

Yakovlev A.S., Evdokimova M.V., Ekologicheskoe normirovanie pochv i upravlenie ikh kachestvom (Environmental regulation of soils and their quality management), Pochvovedenie, 2011, No. 5, pp. 582-596.

Zakharov S.G., Kulik I.V., Tropa i rekreatsionnaya nagruzka: novyi metod opredeleniya uplotneniya pochv na tropakh (Trail and recreational impact: a new method for determining soil compaction on trails), Geograficheskii vestnik, 2017, No. 2, pp. 109-117.

WRB: World Reference Base for Soil Resources, International soil classification system for naming soils and creating legends for soil maps. World Soil Resources Reports, IUSS Working Group. Rome: FAO, 2015, 203 p.

Reviewer: candidate of Biological Sciences, Associate Professor V.V. Kiseleva 